employed, and also on keeping the emotions under due control. Judgments should be clear, accurate, prompt, stable, independent. Clear and sound reasoning depends on clear and sound judgments ; on the clear understanding of the relations between judgments and the terms employed; and on clear attention and imagination (involving discrimination), which keep vividly present the relations of the ideas and the objects with which we are concerned. Fallacies arise mainly from mistaken ideas of identity or similarity.

Here I should like to quote the whole of $\mathrm{Mr}$. Sully's section on the training of the powers of judgment and reasoning, the subject is so difficult, and what he says is so clear and sound. Children, as we know, delight in exaggeration : nothing is so attractive to them as vividness and picturesqueness of statement. Their fancies are active. Their curiosity, except as to what directly helps fancy, is fluctuating and easily satisfied. The anthropomorphic nature of many of their views about nature is startling to those who bave forgotten their own childood. To step in, and seek to repress and change and destroy all this, is to act in distinct opposition to the teaching of nature, - a proceeding which some teachers already recognize as ill-advised and unsafe. Surely a teacher who would destroy a child's delight in fairyland, or its happy belief that its pet dog understood every thing said to it, and the like unjustifiable ideas, would deserve a punishment but little less than that of old inflicted on traitors. Again : unless the child himself forms the judgments and does the reasoning, there is no exercise of his faculties, and therefore no development. But his experience is very small, and his conclusions can seldom be justifiable, even when correct. It cannot be right to encourage him to generalize from insufficient data, and to reason without clear discrimination. In the face of these difficulties, I should advise that we be not in too great a hurry to give a systematic training to the reasoning faculty. The eleventh or twelfth year would be quite early enough, I think, to begin. Meanwhile there is much work to be done in exercising the senses, attention, memory, imagination, and conception ; while the exercise of judgment, which the later stages of this work will introduce, will be quite enough, at first, for our needs. By all means, let us encourage the child's curiosity by affording him the means of feeding and satisfying it. If rightly treated, it will grow by what it feeds upon. When the child cannot, of himself, attain to the knowledge requisite, let us, using a wise discretion, give him an explanation such as he can understand. In this way we shall not interfere with his fancies, though they, in some cases, when too vagrant and emotional, must be gently checked. Difference in the temperament of children should make a difference in their treatment. "But" - and here Mr. Sully speaks - " the training of the reasoning powers includes more than the answering of the spontaneous questionings of children. The learners must be questioned, in their turn, as to the causes of what happens about them. A child cannot be too soon familiarized with the truth that every thing has its cause and its explanation. The mother, or teacher, should aim at fixing a habit of inquiry in the young mind, by repeatedly directing his attention to occurrences, and encouraging him to find out how they take place. He must be induced to go back to his past experiences, to search for analogies, in order to explain the new event. The systematic training of the reasoning-powers must aim at avoiding the errors incident to the processes of induction and deduction. Thus, children must be warned against hasty induction, against taking a mere accidental accompaniment for a condition or cause, against overlooking this plurality of causes. This systematic guidance of the child's inductive processes will be much better carried on by one who bas studied the rules of inductive logic. In like manner the teacher should seek to direct the young reasoner in drawing conclusions from principles, by pointing out to bim the limits of a rule, by helping him to distinguish between cases that do, and those that do not, fall under it, and by familiarizing him with the dangers that lurk in ambiguous language; and here some of the rules of deductive logic will be found useful." Finally, the best subject-matter on which to exercise the child at first will be that connected with common every-day knowledge. Speaking broadly, physical science will best supply us with inductive exercises, and mathematics with deductive exercises. In some subjects of the former, such as botany, chemistry, and physiology, his work will be almost wholly inductive : in some of the latter, such as arithmetic and algebra, his work will be almost wholly deductive.

H. Courthope BoweN.

\section{THE NATURAL METHOD OF TEACHING LANGUAGES.}

THE article on "The ' natural method' of language-teaching," in Science and education for Dec. 24 , closes with the remark that conservatism is not always to be decried, and all innovation is not necessarily good. This thought is so correct that nobody could justly object to it ; and, if all other observations made by the opponents of the natural method be of equal soundness, the cause of this 
much-discussed method would not seem to be as good as its friends might desire. What evokes, however, the reader's doubt at first, is the hig: praise lavished upon the old method, with its tw? mighty cornerstones, - the grammar - book and dictionary. One will naturally ask, If the old and long-established method is really as efficient as its defenders would have us believe, why is it. then, that discontent could arise against it, sprearing to the great dimensions of to-day? Why is it that just the graduates of our colleges, who have had the full benefit of the blessings of the old method, speak frequently, with a very significant smile, of their knowledge of modern languages acquired in their alma mater? Why is it that men of high standing are protesting against that mode of studying which is in vogue in so many of our colleges and schools ? ${ }^{1}$ And why is it that the old method, being so strong and good as is claimed, could be shaken in its very foundation to such a degree that one of its warmest defenders writes but lately," "It is evident to me that the old grammatical method cannot survive the assault of the natural method"?

On the other hand, if the principles of the natural method be as wrong as is said by some of the opponents, it would seem strange that scholars and teachers like Whitney, Thacher, and Hadley of Yale should have permitted their sons to be taught by the founder of the method ; that a man like Prof. Dr. Daniel Sanders declares himself for the method ; ${ }^{3}$ that men throughout the country, prominent in their vocation, are favoring the natural method ; ${ }^{4}$ and that an educational journal which is not friendly inclined towards the method should have recently been forced to admit that "the subject is now attracting great attention in the secondary and higher schools." 5

These discussions in educational and other papers furnish occasionally very interesting reading, and recall to one's mind a well-known story about

1 D. C. Gilman, president of Johns Hopkins university, writes thus to one of the advocates of the natural method, Aug. 15, 1878: "Many years ago Mr. George Ticknor, while professor of modern languages in Harvard, declared, that, although Americans spent as long a time as Germans in acquiring a liberal education, the results in this country were far inferior to those secured abroad. Other recent writers have illustrated the same point, and have shown how much our defleiencies as an educated people have been due to bad methods of teaching both ancient and modern languages."

2 See The academy of December, 1886, p. 339.

3 Referring to a certain set of readers prepared for the natural method, the celebrated German grammarian and lexicographer says to the writer of these lines, in a letter dated March 3,1886, that the method followed therein has his full approval ("dass die darin befolgte Lehrweise meinen vollen Beifall findet").

4 See The natural method, No. 6, vol. il., January edition.

${ }_{5}^{5}$ See The academy of November, p. 301. three professors who were given the task to write the natural history of the camel. None of them n the animal, but they set to work at once following way : the first one retired to his charming study, and, trusting to his vivid imagination, wrote a history as he thought it ought to be ; the second one was busy in the libraries, and, out of all the material collected from books written since the time of Julius Caesar, he gave a natural history of the camel ; the third one alone had departed to the country, where be could see a camel and learn something about it, so that his report might be true to the facts. If it so happens that the reader of the discussions referred to is familiar with the working of the natural method, it will be hard to convince him that all who are passing judgment against it could ever have tried the method practically and earnestly, or could even have seen a complete course given.

The question has been raised, 'Is the natural method a method at all ?' If it be correct that the term 'method' signifies 'a series of means purporting to lead to some desired end,' then the question must be answered in the affirmative. All the rules of the method pertain either to matter or to the individual.

First, it is required that one should proceed in the treatment of the language and in the treatment of the laws of language ; i.e., grammar, in accordance with that method, which, ever since Bacon's time, has been the acknowledged method for true study, - the inductive method.

Second, it is required that the treatment of matter after the inductive method should vary as the individuals who are taught vary in age, character, ability, and preparation.

To fulfil these requirements to the best advantage, it was found necessary to establish the general rule that the language which is to be taught. must serve exclusively as means of communication between teacher and learner.

There is nothing especially new in either of these requirements ; in fact, one or the other of them has been successfully employed at various periods by different methods: but the united application of them has been first attempted by the natural method ; and it is this united application that causes recolution in language-teaching. It is needless to repeat here that the credit of the innovation is due to Prof. Gottlieb Heness of New Haven, Conn. The special training in the principles of Pestalozzi, which he received in the Lehrer Seminar, ${ }^{1}$ and peculiar experiences in the teaching of children, had led him to those conclusions with which we are now acquainted. To

1 A German institution in which young men are prepared who intend to teach in the public schools. 
assume, however, that his method is merely a method for children, because some of his first experiments through which he arrived at certain principles were made in children's classes, is as erroneous as to believe the perusal of the various readers give an insight into the real characer of the natural method. Let us now see if the method is capable, in certain measure, of satisfying the demands of the ideal method which the writer of the article in Science and education has outlined. The rational method, as he chooses to term the wished-for ideal method, "would take. wherever it find them, all pedagogical methods of undoubted value, and incorporate them in its in-struction." This condition, I doubt not in the least, the natural method fulfils well. The writer himself says complainingly in his article, "Since they [that is, the claims of the most enthusiastic votaries of the natural method] were first formulated, the details of the system have grown by a not unnatural accretion, until they include a great mass of pedagogical material, some of which is about as much the especial property of the natural method as spectrum analysis is.an individual prerogative of the pupils of Helmholtz. From one point of view, this is, perhaps, not to be deprecated ; for, through the active proselytizing of its disciples, sound pedagegical principles have obtained a currency and found their way where otherwise they might not so easily have penetrated." •

Then the rational method "would, above all, use the language taught at every possible opportunity, and make its practical acquisition the one end in view." Ever since the natural method has been brought to light, its advocates have preached and practised the rule of using the language taught at every possible opportunity; and some teachers have, in fact, acquired such a skill in using the language taught that they never will use any other while teaching; nor do they lose any more time while explaining or giving definitions than a teacher of the old method would by using English.

Third, according to a rational method, "the grammar and dictionary are effete in modernlanguage instruction if they are taught for themselves alone." I believe no one has as yet reproached the natural method for having ever taught grammar and dictionary 'for themselves alone.'

Fourth, a rational method would give the good advice, " Regard them [dictionary and grammar] as they sbould be regarded, as auxiliaries, and employ them in that way." During more than twenty years the advocates of the natural method have been teaching constantly this doctrine, which their opponents explained in their own way, accusing the method of neglecting the teaching of grammar, while the criticism justly should have been directed against the unthorough, unsystematical, go-as-you-please way of certain teachers they had met with. But, if they had been present for a single hour in a class conducted by the founder of the method, they would have had the opportunity of seeing grammar taught svstematically, after the inductive method; and had they asked the question, "Why are the words 'without dictionary and grammar' printed on the titlepages of your books and pamphlets?" they would have received his answer: "If you call this [referring to his teaching the principles of the construction of the language] grammar. you are at liberty to tell the world that $I$ teach grammar." And, indeed, critics should know this, once and forever: the natural method not only teaches grammar, but teaches it more thoroughly than possibly could be done by the old method. ${ }^{1}$

Fifth, the rational method " would have extracts furnished at the outset with a special vocabulary which would be learned." Almost every one of the many readers published already for the natural method gives a large supply of such extracts ; and they are in some of the best of these readers so selected and arranged that the words must necessarily impress themselves on the student's mind without any memorizing at all.

Sixth, "later on" the rational method " would inculcate the use of the dictionary." The natural method is always ready to comply with this demand, though it must respectfully decline to take a text-book of grammar as a 'cornerstone ;' and, in this view, it has on its side the opinions of learned men of various times. ${ }^{2}$

A great deal has been said of late about the

1 See 'A plan for twenty-eight lessons for the class in French,' or 'Program of October, 1886,' both published by Stern's School of languages of New York City.

2 "One can learn the grammar from the language, and not the language from the grammar."-JOHANN GOTTFRIED VON HERDER

Prof. Rudolph Hildebrand, editor of the great German dictionary begun by Grimm, says in 'Vom deutschen Sprachunterricht in der Schule,' "Der Lehrer des Deutschen sollte nichts lehren was die Schüler selbst aus sich flnden können."

"One should begin with the spoken language with sentences, and from the audible language one should proceed to written language. Reading must be considered as the centre of language-teaching, and in connection with it grammar must be taught inductively : the learner must be guided so as to find for himself the laws of language." - Internationale Zeitschrift fïr allgemeine Sprachwissenschaft, band ii. heft 1. (Leipzig).

"The language is not to be learned from the grammar, but from and through the language."-SCHRADER, vii. p. 241.

"The grammar must not precede, but follow."-GRAF voN PFEI, in Wie lernt man eine fremde Sprache, p. 31. 
name 'the natural method,' and of the success being due to that name. For those who lay so much stress on the name, it will be interesting to learn that neither the founder of the method, nor some of the most prominent exponents, had any thing to do with the giving of the name. One of Harvard's learned professors has done the method the honor to christen it; and a research after the true motives for selecting just that name, with all its meanings, is certainly a worthy subject for investigation. But to attribute the popularity of the method solely or mostly to its name, seems hardly to be reasonable. To my judgment, . it is the truth of the method, the zeal and energy of its followers, and the muchfelt need of better methods in general, which explain the conquering power of the natural method.

Sigmon M. STERN.

\section{THE TRAINING OF TEACHERS. ${ }^{1}$}

THE profound significance of the teacher's profession is not yet properly recognized. Many men, of considerable intelligence even, think that school education covers too narrow a field of life to have facts and principles capable of constituting a science, and that teachers of common schools are but day-laborers, having no professional standing, and hence needing no professional training. On this account, our normal schools will have many trials to meet, and many difficulties to overcome, before reaching the position towards which they are struggling.

As yet. our advanced high schools and colleges do not supply these schools with a sufficient number of students whose thorough literary attainments warrant a more exclusively professional course of studies. In fact, our normal schools are necessitated to do this preparatory academic work themselves. In this way they render themselves liable to the charge of being only academies with a quasi-professional annex.

We have all along very much regretted the necessity of directing so much attention to the academic training of the students in these schools, and have carefully studied how to keep the purely professional element from being too much neglected, without, at the same time, sacrificing the thorough literary instruction required.

The large supply of teachers required for the educational work of the state, and the very low average of salaries given for educational labor, make it almost impossible to lengthen very much the present term of study. Some, with great earnestness, have advocated the addition of an-

1 From the annual report of E. E. Higbee, superin endent of public instruction of the state of Pennsylvania. other year. In due time this will come, and be of immense account in enlarging the sphere of professional studies, and giving opportunity for more definite and continuous model practice, which, when rightly conducted, is of so much value.

The literary instruction may have been given in harmony with the best principles which the present philosophy of school education is able to give, and in such form as to bring into view the very best methods which either the science or art of teaching furnishes. We are not calling this in question at all; but we must keep in mind that the students, at the very outset, are backward in their literary studies, and have but little knowledge of psychology. Hence they are forced to make every exertion in preparing for their daily class-work, and must be, of necessity, far more anxious about the matter of what is taught than about the manner or method of teaching it. They fear to spend any more time in the model school than is absolutely required by law. They make the minimum here the maximum, if they can. In addition to this, being subject at the close of the course to a rigid state examination, covering all the academic studies pursued, they, with their professors, are tempted to sacrifice all efforts towards enlarging the course of professional studies through fear of the issue of the final examination-test.

Although the course of studies as now arranged is not very satisfactory to us; and will need, in our judgment, some important changes, yet we have felt constrained to approve it on account of our great anxiety that the graduating year should be given more fully to the work of professional training, taking up the whole history and science of school-teaching, and illustrating in detail the psychological ground of every method by a greatly enlarged course of practice in the model school. Such practice, in our judgment, is very essential. Indeed, it sustains the same relation to the normalschool studies as a moot-court does to a law-school. Here theory finds verification; here principles pass into direct conscious application; here science makes its transition to art; here the furnished scholar learns to handle with vigor his whole armor, as a page when he became a belted knight and entered the tourney. The teacher needs scholarship, of course, but he needs something more : be must have knowledge, and, at the same time, thoroughly master the art of imparting it. To this end our normal schools were established; in this direction they steadily tend. In the above plan, however, no one thought for a moment of not holding with firm grasp the essential truth that professional knowledge cannot exclude schol- 